\title{
Local and Global in the Formation of a Learning Theorist: Peter Jarvis and Adult Education
}

\section{John Holford}

University of Nottingham

john.holford@nottingham.ac.uk

Biographical note:

John Holford is Robert Peers Professor of Adult Education at the University of Nottingham, and an Editor of the International Journal of Lifelong Education.

\section{Keywords:}

Peter Jarvis; intellectual biography; adult education; learning; lifelong learning

\section{Abstract}

Peter Jarvis is a towering figure in the study of adult and lifelong education, and a leading and original theorist of learning. This paper sets out his intellectual and professional biography, maps the main contours of his work, and introduces fourteen papers by leading scholars devoted to his work. Five broad phases in Jarvis's life are identified: (a) youth, self-education, Methodist ministry, and early teaching and research; (b) founding of the International Journal of Lifelong Education, authorship of important textbooks on adult and professional education, and linking of academic communities in different countries; (c) early research on and theorisation of learning; (d) engagement from the early 1990s with debates on lifelong learning and the learning society; and (e) return to theorisation of learning, particularly from the perspective of globalisation, from around 2000. Recurring themes include ethics and responsibility, the essentially social nature of learning, democracy, and authenticity in human relationships. 


\section{Local and Global in the Formation of a Learning Theorist: Peter Jarvis and Adult Education}

John Holford

Sownynge in moral vertu was his speche,

And gladly wolde he lerne, and gladly teche.

(Chaucer: Prologue to The Canterbury Tales) ${ }^{1}$

Over the past forty years, Peter Jarvis has established himself as a towering figure in the study of adult and lifelong education, and as a leading and original theorist of learning. In this double special issue of the Journal, leading scholars from around the world explore, evaluate and build on his work. In this introduction I provide a sketch of Peter's life, focussing on his professional and intellectual formation and contribution, before discussing the various contributions.

In a volume such as this, some biographical contribution is probably de rigueur; but if justification be required, Peter has provided one. 'It is through the process of living and learning,' he wrote, 'that we gain wisdom' (Jarvis, 2009a, p. 63). Our experiences are, of course - as he has also written 'embedded within our own biographies' (Jarvis, 2009a, p. 89). Intellectual biography is a wellestablished genre: though it can be only a fragmentary prologomenon to a full intellectual biography, I hope this outline of Peter Jarvis's life and intellectual activities will illuminate and contextualise the substantial studies that make up the remainder of this special issue.

If Peter's standing in adult education and learning theory provides justification enough for a double special issue such as this, the occasion is twofold: during 2017, Peter celebrates his $80^{\text {th }}$ birthday, while at the beginning of last year - 2016 - he stood down after 36 years as co-editor of our journal, which he founded. To mark this contribution, the editors of the International Journal of Lifelong Education invited scholars from around the world who respected his work and valued him as a person to contribute. Peter's friends, and those who respect and value his work, are numerous: we could not extend an invitation to all. In making the selection, we were guided by a range of criteria. We aimed to include scholars from around the world - reflecting Peter's commitment to an international scholarly community. We aimed to include contributions which addressed the depth and breadth of Peter's intellectual engagement. We aimed, as Peter has long done, to include younger as well as established scholars. Because teaching has been central to Peter's scholarly contribution, we wished to include his students. And we sought to involve some who have collaborated with Peter in academic enterprises. We think we have met all these criteria, though in different ways. Inevitably, however, we were unable to include many who deserved to be approached, and whose work would have enhanced the special issue. We hope they are not offended; but they should know that Peter is not responsible.

Peter is a major figure, and one all of us, the contributors to this double special issue, respect. We have approached our tasks in a spirit we believe he values: as colleagues committed to the humane development of adult education, the field to which Peter has committed his intellectual life. All of us 
recognise his signal contribution. We also know that honest criticism is among the qualities he encourages. We have, therefore, sought to praise Peter not by flattering him, but by engaging in serious intellectual debate with his ideas, theories and arguments.

Most if not all the contributing authors have an interest to declare - that they like and respect Peter Jarvis. Before proceeding further, however, I should say a little on my own account. I first met Peter in 1985, shortly after I enrolled on the M.Sc. he taught at the University of Surrey. I had applied partly because Peter's writing on adult education was already recognised. I was not disappointed: he proved a committed and inspiring teacher. When, a few years later, I moved to the University of Hong Kong, I encouraged - and occasionally supported - his enthusiasm for intercontinental travel. In the mid-1990s he strongly encouraged me to move back to Surrey; I did so, and worked quite closely with him. He had become, by then, a good and loyal friend; he has remained so, the vicissitudes of Surrey life notwithstanding. When I arrived he was my head of department; by the time I moved on a decade later I had been his. We had experienced the closure of the department in which Peter spent most of his working life, from which I had graduated, and which we had both led. For nearly two decades we collaborated in editing this journal. We have thought, debated, argued, researched and written together. Quite often we have disagreed: as he knows my flaws, so I have seen his. But his intellectual and moral strengths, his energy, his affection for and generosity to his fellow men and women, have enriched my professional and personal life, as I know they have enriched countless others'.

\section{Methodism and Education}

Peter Jarvis was born in Gillingham, Kent, on 1 July 1937. The county of Kent, south-east of London, is often described as the 'garden of England'. Until well after the Second World War, working-class families would come down from London's East End for working holidays picking apples, soft fruit, and hops. ${ }^{2}$ But, especially on its northern shores, the county has long been much more than agricultural. The town of Gillingham, nestling on the estuary of the River Medway, merges imperceptibly into Chatham, which itself transitions seamlessly into Rochester - which is separated from Strood only by the river. In the mid-twentieth century they formed, in effect, a small industrial city, home to several large engineering factories, cement works and paper mills. The Medway Towns' industrial heart, however, was Chatham Dockyard: one of a series of so-called Royal Dockyards scattered around the British coast - and indeed, around the Empire - that built and repaired warships for what was then still the largest navy in the world. Some 11,000 men and 2,000 women worked at Chatham Dockyard during the War (MacDougall, 1981, p. 152); among them, a shipwright, was Peter's father.

A craftsman's wage would no doubt have provided an adequate family income, but when Peter was aged just eight his father was killed in a road accident. Times were hard. The welfare state - this was immediately after the war-remained unborn. To supplement the family income Peter worked in a dairy from the age of ten until he left school. But he passed the 'eleven plus', and went to Gillingham Grammar School. Clearly as energetic then as now, he became not only a first rate tennis player - he played at the Wimbledon junior championships - but a lay preacher. He was, as he remains, a Methodist. He preached his first sermon - and gave his first lecture - in 1954, at Novi Sad during the first post-war British schools' visit to Yugoslavia (Jarvis, Rabušicová, \& Nehyba, 2015). 
With so busy an 'extra-curricular' life, Peter did not enjoy great academic success at grammar school. He failed his A-levels. Leaving school, he volunteered for the Royal Air Force. After three years' service (1955-58), he left to prepare himself for the Methodist Ministry, first at Cliff College in Derbyshire, later at Richmond College - part of London University. But something had reignited his desire for academic advance; perhaps it was Maureen, whom he married in 1962. He became what would later be known as a 'second-chance' student. While at Richmond, he turned his energies to his own broader education. Without additional tuition he took and passed two A-levels, which meant he could study for a degree, rather than a diploma, in Theology. Having graduated with a Bachelor's degree (B.D.) in 1963, and been ordained as a Minister in the Methodist Church, he was assigned to pastoral work in Sheffield, then the centre of Britain's steel industry. He had progressed from school 'drop-out' not only to a degree, but to a calling.

As a minister in Sheffield, in his mid-20s, Peter became responsible for four churches - quite enough for many men. Yet at the same time, he studied full-time for a BA in Sociology at Sheffield University. Having graduated (in 1969), he left the full-time ministry (though he remains to this day a Methodist Minister - the minutes of the 2015 Methodist Conference record 'The Revd Prof Peter Jarvis' among the names of 'presbyters' to whom it had sent letters 'on the occasion of the 50th anniversary of their ordinations'). He took up a post as Lecturer in Sociology at Dudley College of Education, near Wolverhampton in England's West Midlands. By then he had caught the study bug; he enrolled for a part-time Masters in Sociology by research at Birmingham University (graduating in 1972) and then (again part-time) for a PhD at Aston University. ${ }^{3} \mathrm{He}$ had also caught the teaching adults bug: when Peter became one of the Open University's part-time tutors in 1971, and for many years it and its students were an important part of his life: he remained one of its tutors for the next thirty years, and also served for nine years as an assistant staff tutor and, briefly, as acting staff tutor.

In 1976, aged 39, Peter was appointed to a Lectureship in the Department of Adult Education at the University of Surrey; and at Surrey he has remained. ${ }^{4}$ In due course he was promoted: Senior Lecturer, Reader, then to a personal chair in Continuing Education; since 2010 he has been Emeritus Professor. He contributed to extra-mural teaching, but pretty soon after completing his PhD in 1977 his ideas grew more ambitious. Perhaps he was helped because Education at Surrey in the 1970s and 1980s was a vibrant and growing - if not always even-tempered - department. Very soon the Department of Adult Education had been merged with the Institute of Educational Technology to form the Department of Educational Studies. That and subsequent reorganisation - particularly stemming from drastic funding cuts in the early 1980s - brought in several new staff, particularly from the excellent, but newly-abolished, Philosophy department. Whatever the reason, Peter's colleagues were innovative, insightful and interdisciplinary. ${ }^{5}$

Teaching at Surrey engaged many of Peter's creative energies. He played an important part in developing the Postgraduate Certificate in the Education of Adults (PGCEA), that was for years one of the mainstays of the Department's work. While many of its students came from adult and further education, its impact was perhaps even greater in professions, particularly nursing and midwifery, which were increasingly recognising the importance of both initial and continuing education. Students could move on from the PGCEA to the M.Sc. in Educational Studies: for many years Peter taught a course on Adult and Continuing Education: students (including two contributors to this volume: Lore Arthur and me) travelled from all over South-East England to study with him on 
Wednesday afternoons. Later, partly because it became more difficult to recruit to on-campus courses during the 1990s, Peter pioneered a Master's degree in adult education by distance learning. ${ }^{6}$

\section{From Teaching to Writing}

Before arriving in Surrey Peter had begun to publish, with articles in the religious and professional educational development press (e.g., The Methodist Recorder, Bulletin of the Association of Religious Education), as well as papers based on his M.Soc.Sc. and Ph.D. studies in mainstream academic journals (e.g., Sociological Review, Journal of Moral Education). But Surrey provided a new focus: he turned his authorial attention to the areas in which he taught. This knack - aligning academic writing with teaching - is something many of us strive to achieve. The common solution is the writing of textbooks; and - although disparaged today in many research quality assessment regimes - is a vital contribution many scholars make to the wider academic community. Some of Peter's work especially perhaps two books he wrote towards the end of his first decade at Surrey - were in the way of textbooks: Professional Education (Jarvis, 1983c) and Adult and Continuing Education: Theory and Practice (Jarvis, 1983a) fall into this category. Here we find Peter writing in order to make sense of the field he was teaching: they are books which review the themes and issues in the field, and do so in large part by reviewing the literature. In Professional Education, to be sure, we can detect the familiarity with the literature on professions which comes with having written a PhD thesis on the topic. As he acknowledges, however, 'some stimulating sessions' with PGCEA students, all 'preparing to teach adults, mostly in the professions', had helped 'to clarify my thoughts' (Jarvis, 1983c, p. ix). The book was an innovative attempt to explore professionalisation in relation to educational issues such as curriculum, knowledge and teaching.

If Professional Education was the product of the PGCEA, so too was Adult and Continuing Education: Theory and Practice, though one senses that it also drew also on his M.Sc. teaching. The book had a broader target audience, attempting to address the growth in introductory training courses for teachers of adults that had followed an influential report (Haycocks, 1978). In the Introduction, Peter set out his purpose: the study of adult education was 'growing in significance as the training of educators of adults' was becoming more common, but there were 'few textbooks that seek to introduce students to the broad sweep of the field' (Jarvis, 1983a, p. xv). Theory and Practice unquestionably did that: it mapped the field in a way previously unattempted in Britain, and in a way that has shaped the studies of countless adult education students since. ${ }^{7} \mathrm{It}$ is, of course, now in its fourth edition (Jarvis, 2010): and while each edition (Jarvis, 1995, 2004) has broadly the same shape as its immediate predecessor, each was genuinely revised in the light of the changing field: Adult Education and Lifelong Learning: Theory and Practice (as it is now entitled) is no mere 'retread'.

By the mid-1980s the pace of Peter's scholarly writing had reached the pitch which has made him legendary in the field across the world. His next two books also drew strongly on his teaching of professional adult educators. With 'encouragement of students following the [PGCEA] sociology of education course' and the M.Sc. 'Adult Education option', Peter wrote The Sociology of Adult and Continuing Education (Jarvis, 1985). He filled a definite gap. The growth of interest in the sociology of education in the early 1970s had focussed overwhelmingly on initial education (e.g.,Whitty \& Young, 1976; Young, 1971; Young \& Whitty, 1977). Peter mapped the different ways in which 
sociological perspectives could be applied to adult education. Attempting 'to draw on all branches of sociology', but 'not ... to argue any case', however, the book 'espouses no ideological viewpoint', (Jarvis, 1985, p. xiii), and perhaps as a result Peter's Sociology has not been among his most influential works. ${ }^{8}$ The Teacher Practitioner in Nursing, Midwifery and Health Visiting, on which Peter collaborated with his Surrey colleague Sheila Gibson, (Jarvis \& Gibson, 1985) reflected the growing enrolment of these professionals on the PGCEA, and responded to the growing recognition of the need for continuing professional education in those fields. A revised edition appeared twelve years later (Jarvis \& Gibson, 1997).

The books Peter wrote in his first decade at Surrey made a mark: but his other scholarly activities were in many ways equally impressive, and arguably of even greater long-term significance. First of all, he published articles regularly in academic, professional and religious journals: somewhere between three and seven papers in every year bar one. His academic papers were now appearing in two main areas: adult education (e.g., Jarvis, 1984), and nursing education (e.g., Jarvis \& Gibson, 1981 ) - though with some in the area of pre-retirement education (Surrey was home to the PreRetirement Association) and learning in later life (e.g., Jarvis, 1983b). In that year (1980/81) we detect that he was busy in a different way: he was founding the International Journal of Lifelong Education, whose first number appeared early in $1982 .{ }^{9}$ And in 1987 he published his first major edited book, Twentieth Century Thinkers in Adult Education (Jarvis, 1987b) - a book which asserted and discussed the significance of half-forgotten thinkers (e.g., Yeaxlee), of those whose significance as adult educators was then ill-recognised (e.g., Dewey), of contemporary North American theorists (Houle, Knowles, Kidd), and of theorists of social change (Coady, Horton, Freire, Gelpi). This book, too, he wrote, had been prompted and 'took shape over a number of years of teaching the theory of adult education', when he had become aware that no single book 'provided an overview of the variety of approaches to the subject nor ... summaries ... of the key thinkers' (Jarvis, 1987b, p. vii). Finally, he had initiated two major book series with Croom Helm (then a small but dynamic academic publishing house): The Croom Helm Series in International Adult Education (around twenty books, including ground-breaking contributions such as Gelpi (1985) and Griffin (1987) and The Croom Helm Series on the Theory and Practice of Adult Education in North America (around ten books, of which several including Brookfield's edition of Eduard Lindeman's work (Brookfield, 1987), Collins (1991), Courtney (1991), Marsick (1987), and Watkins and Marsick (1990) continue to be significant). ${ }^{10}$

\section{The Learning Turn}

From the mid-1980s Peter's publishing took a new turn. His next book, Adult Learning in the Social Context (Jarvis, 1987a) made his mark not only as a codifier of knowledge and advocate of a field, but as an original researcher and thinker. In some respects, it shows common features with its predecessors: it was based on extensive scholarship and critical reading; it sought to organise and analyse what had been written; and it involved interaction with students. Unlike in the earlier works, however, the students had been involved as research subjects: this was empirical, and original, research. This book - and the later evolution of his thinking on learning - is discussed in several contributions to the present volume; at this point we need perhaps only note his starting point and his conclusion: 
The behaviouristic approach to learning, because it was researched under 'scientific' conditions, assumed higher status in teaching theory than perhaps it deserved. But more than this, it actually artificialised the normal, natural processes of learning and, therefore, failed to examine the richness and completeness of the human learning process....

People are the result of learning and continue to be what they are because of learning. Whilst learning and living are not the same phenomenon, they are co-termin[o]us, and those who help others learn (whether or not they are called teachers) bear some of the responsibility for helping people grow (Jarvis, 1987a, p. 206)

Although Peter's views on learning have evolved and become more sophisticated in subsequent years, the conclusion in many ways encapsulates the core of his thinking. It was significant, and its importance was recognised not only at the time (for example, by winning the Cyril O. Houle Award of the American Association for Adult and Continuing Education), ${ }^{11}$ but subsequently (cf Illeris, 2007, 2009).

The mushrooming of Peter's intellectual output in the 1980s made him something of an international celebrity. Unusually for British adult educators at that time, he had begun to participate in North American conferences (the Adult Education Research Conference, the American Association of Adult and Continuing Education (AAACE), and the Commission of Professors of Adult Education); he was invited to make guest lectures at North American universities ${ }^{12}$. Together with his editorship of book series and of the International Journal of Lifelong Education, he became a key bridge between British and American scholarship in the field. While in Britain he could appear to be opening us to American ideas, he was also informing Americans about developments on his side of the Atlantic (see, e.g., Jarvis, 1988). He also began travelling more widely: in the later 1980s we find him speaking, for instance, in Barcelona, Copenhagen, Dublin, Helsinki, Hong Kong, Leuven, Nijmegen, Sydney and at Nankai University in Tianjin. Peter has combined a remarkable talent to work alone - the great bulk of his writing has been single-authored - with a capacity to be gregarious and a genuine love of people as individual human beings. John Wesley, the founder of Methodism, advised its adherents to 'labour to avoid all real unkindness, all disobliging words, or harshness of speech, all shyness, or strangeness of behaviour'. (Wesley, 1745) No-one who gives so much time to writing and scholarly activity can avoid occasionally acting in strange ways; but in other respects Peter's remarkable capacity for productive networking is testament to his internalisation of Wesley's counsel.

Moving into the 1990s, therefore, Peter was well-established as a scholar of international standing. At this stage - rather late, many thought - Surrey promoted him to a personal chair. But quite soon thereafter, he became, as it were, collateral damage of a crisis at Surrey. Under strong pressure from above and below, he took over as Head of the Department of Educational Studies. During a very difficult period, he believes he succeeded in saving the department from abolition; but it was not a role he relished. One might imagine that it diverted his attentions from his true vocation - teaching and writing - though this is not evident in the volume of his publications, which became if anything more numerous in this decade. In the single academic year 1995/96, for instance, he published 24 articles and chapters, including five in refereed journals; in most years of the decade his 'output' was well into double figures. And of course the books kept coming: the International Dictionary of Adult 
and Continuing Education (Jarvis, 1990), Training Adult Educators in Western Europe (Jarvis \& Chadwick, 1991), and - something of a coup - Adult Education: Evolution and Achievements in a Developing Field of Study (Peters \& Jarvis, 1991), the AAACE's first attempt to issue a successor to its famed 'black book' (Jensen, Liveright, \& Hellenbeck, 1964). With his Surrey colleague Nick Walters a community educator and Church of England priest - he edited Adult Education and Theological Interpretations (Jarvis \& Walters, 1993).

Nor was this period marked only by edited books: Paradoxes of Learning: On becoming an individual in society (Jarvis, 1992) was his second major book on learning. It perhaps sets the tone for several of his later works: starting from the empirical core he had set out five years earlier (Jarvis, 1987a), it explored the implications and significance of this line of thinking across a range of philosophical, sociological and psychological dimensions, and in relation to key areas (ageing, the workplace, politics, and so forth). The essential argument was encapsulated in the title: learning is situated 'in the paradox of the human condition':

This paradox is summed up by the contradictions of living in society: there can be no freedom without constraint, no certainty without uncertainty, no truth without falsehood, no joy without sorrow, no sense of peace without threat of war, and so on. Above all, there can be no learning without ignorance and no growth and development without learning. But even more important, people seek meaning for their lives and discover that only as one meaning unfolds, still more questions lie beyond it. (Jarvis, 1992, p. xi).

The target readership of the book was ambitiously wide: 'all scholars and practitioners involved with any aspect of human learning' (Jarvis, 1992, p. xii); one of Peter's increasing concerns was to speak to this broad field, to encourage it to recognise its commonalities, and to recognise that helping or encouraging learning was a profoundly moral activity. In one respect, of course, his thinking paralleled - and perhaps even contributed to - what has been called the 'learning turn': the 1990s foregrounding of concepts such as 'lifelong learning' and the 'learning society'. But his strongly moral compass, and his emphasis on learning as integral to 'personhood', sets him aside from the decade's increasingly skills-for-the-workplace focus.

His second authored book of this period, Adult Education and the State (Jarvis, 1993), was subtitled 'towards a politics of adult education'. It is clearly an effort to come to terms with the darker side of the learning turn: with the 'increasing emphasis on vocational education and training ... the various forms of adult education have now become an element in government policy' (Jarvis, 1993, p. vi). In approach, it is not unlike several or his early books - a critical engagement with literature - and represented a timely effort to engage with the dimension of power, and provided a grounding for some of the - more substantial and more successful - forays Peter made into citizenship and democracy during the following decade (see esp. Jarvis, 2008).

\section{Lifelong Learning and Ethics}

Peter stood down as head of department - with, one suspects, some sense of relief - in mid-1996. He refocussed on research, and did so partly by building a small but collegial group around him. Initially known as the Lifelong Learning Research Group (from 1999 it became the Centre for Research in Lifelong Learning (CRILL)), this was very much a group in Peter's image: it began very 
informally, as a small seminar group whose members committed themselves not only to writing and presenting papers, but to reading one anothers' papers in advance of meetings. The earliest members, along with Peter, were Colin Griffin and me. Colin, then a lecturer at Hillcroft College, the residential college for women at Surbiton in Surrey, was a close intellectual companion. He and Peter had met in the early 1980s, when Colin contributed two important papers to the International Journal of Lifelong Education (Griffin, 1982, 1983b); at much the same time Colin's important book on Curriculum Theory in Adult and Lifelong Education (Griffin, 1983a) appeared. He then joined the University as a part-time Associate Lecturer. Peter and he co-taught the Adult Education option of the M.Sc.; Colin also contributed to the PGCEA. I had studied part-time for the M.Sc. in the mid1980s, and rejoined the Department in 1996. As time passed, though other colleagues joined us, ${ }^{13}$ it remained a small and relatively intimate group, and Peter was able to draw it into intellectually and professionally profitable work - particularly developing members' publications through collaborative writing projects (Jarvis, 2001c, 2002).

This group provided Peter with a valuable intellectual home for several years. Right at the outset, it undertook a small empirical research project on a learning voucher scheme in London (Jarvis, Holford, Griffin, \& Dubelaar, 1997). ${ }^{14}$ Over the next couple of years the group busied itself with various initiatives: an international conference ('Lifelong Learning: Rhetoric, Reality and Public Policy', held in Guildford in 1997) led to a useful edited collection (Holford, Jarvis, \& Griffin, 1998); collaborative writing (in particular, The Theory and Practice of Learning (Jarvis, Holford, \& Griffin, 1998) and The Age of Learning (Jarvis, 2001c)), and what often seemed the endless project resulted in the five-volume Adult and Continuing Education: Major Themes in Education (Jarvis \& Griffin, 2003a, 2003b, 2003c, 2003d, 2003e). ${ }^{15}$ Working with the group, Peter engaged with the Labour government's developing lifelong learning agenda (e.g., National Advisory Group for Continuing Education and Lifelong Learning (1997) and The Learning Age green paper (Department for Education and Employment, 1998)), including in the professional press (e.g., Jarvis, Griffin, Holford, Merricks, \& Tosey, 1998), and generated some very valuable work. ${ }^{16}$

Typically, while his colleagues in the Lifelong Learning Research group thought they were writing hard, Peter wrote harder - and faster. ${ }^{17}$ It was during these years that Ethics and Education for Adults in a Late Modern Society (Jarvis, 1997) appeared, followed in rapid succession by a revised edition of The Teacher Practitioner and Mentor in Nursing, Midwifery, Health Visiting and the Social Services (Jarvis \& Gibson, 1997), The Human Resource Development Handbook (Hargreaves \& Jarvis, 1998), The Practitioner-Researcher (Jarvis, 1998), a revised - and now co-authored - edition of the International Dictionary of Adult and Continuing Education (Jarvis \& Wilson, 1999), Learning in Later Life: An Introduction for Educators and Carers (Jarvis, 2001a), and Universities and Corporate Universities: The Higher Learning Industry in Global Society (Jarvis, 2001b). Though Peter was now in his mid-sixties, he showed no signs of slowing down. Neither was there much let-up in his production of articles: in the year 2001/01, for instance, 21 were published, three of which were in refereed journals.

Neither were these books mere 'pot-boilers'. Paradoxes, for instance, reflected in part Peter's involvement as a non-executive director of a private company, the Management Consultancy Business School, whose purpose was to develop qualifications for management consultants. It may also be seen as in the tradition of John Heron and Surrey's Human Potential research group; 
although Peter was never closely involved with such work, it was part of the intellectual community in Educational Studies at Surrey. But it is a sustained attempt - and in many ways a successful one to validate professionals who undertake research as part of their working life: 'a new breed' whose research 'is often small-scale and frequently not defined as research by the research community' (Jarvis, 1998, p. xi). Peter's case was that 'all practitioners generate their own personal theories, and that apparently objective knowledge of traditional theory is no more than information to be learned and experimented with in practice' (Jarvis, 1998, p. xii). It is clearly of a piece with his thinking on learning, and reflects the respect in which he holds his students and their work. But one can also sense his awareness that the advances in learning theory he had made, though not 'practitioner research' in this precise sense, were based on and demonstrated the value of small-scale empirical research.

Ethics also remains important, perhaps most of all because in it Peter addressed ethical issues across many fields: distance education, assessment, self-directed and contract learning, the role of markets, and so on. His argument was a characteristically human one: 'there is one universal value - being concerned for the Other - and that ethics begins when the Other impinges on my spontaneity'. But, he argued, 'there are now forms of education where the universal value has been almost eradicated from the learning process - the amorality of learning within an advanced capitalist system is becoming the order of the day'.

[T] he processes of teaching and learning are processes where putting the universal value of people caring for people into practice costs money and so it is becoming less dominant in the education system. When people have no time for people the face becomes a stranger, the Other no longer impinges upon my spontaneity and the universal ethic is subsumed into relative, cultural values and education has become depersonalised. If this were to occur the learning society, hailed by many, would be impoverished. (Jarvis, 1997, p. 174)

Educators, he argued, should 'strive to avoid this', because, 'paradoxically' when 'available for learners' they would be more likely to generate a 'teaching and learning system where each individual's potential stands a better chance of being achieved and, perhaps, ... be a step towards the good society to which may of us who advocate the learning society look forward.' (Jarvis, 1997, p. 174).

Re-reading Peter's work from this period, one senses the influence of post-modernism: while he never advocated 'post-modern' theories in the way we find, for instance, in Usher and Edwards (1994) or Olssen (1999), he was clearly influenced by them, and needing to position himself in relation to the challenges they posed. He refers often to the work of Bauman, Foucault and Lyotard in books such as Ethics, the Practitioner-Researcher, and Universities and Corporate Universities (Jarvis, 2001b). Intellectually, Peter has always been a surfer: abreast of the main currents of the time, intrigued by new ideas, enjoying the possibilities posed by innovative approaches and novel theories. Sometimes he has almost seemed a 'neophile'. But in the end, he has never been swept away by the tide: his perspectives have been grounded in his love of, and respect for, the human; and in his sense that humanity is constructed through social interaction.

\section{Learning, Democracy and Globalisation}


Peter reached formal retirement age in 2002. He did not, of course, actually retire - he continued to be employed at Surrey for another eight years, though on a steadily more part-time basis, applying this paid time chiefly to the supervision of the doctoral students who have long been so important a part of his life (two of his doctoral students, Lore Arthur and Martin Dyke, have contributed articles below). Inevitably he became less central to the Surrey Department (or as it was for a few years around the millennium, School) of Educational Studies. Institutionally, times were increasingly hard for adult education in Britain. In one of those paradoxes which litter history, as the government argued more for the importance of lifelong learning, so it progressively dismantled the institutional structures of adult education (Holford \& Welikala, 2013). University adult education departments and notwithstanding its name, Educational Studies at Surrey was very much an adult education department - were rebranded, downsized, repositioned, restructured, and (far too often) closed. Surrey did not escape the trend: after several years of escalating crisis, it closed in 2004. In its place, the University opened a Department of Politics ${ }^{18}$ for the first time; several Educational Studies staff made the transfer, though - in a bruising process - several found themselves surplus to requirements. Probably wisely, Peter largely stood aside from this unpleasantness, though he was of course not unaffected by the closure of the department which provided his professional home for over a quarter-century. One casualty was the close-knit research group on lifelong learning, whose members were sucked into formulating and managing 'rescue' plans and strategies, and in several cases dispersed into entirely separate departments.

Inevitably, Peter found himself other activities. He and Maureen had moved from Guildford to Thatcham, west of Reading, in 2001, and he took up an honorary fellowship at Sarum College in Salisbury, an an ecumenical centre for Christian study and research. He continued to travel: having participated in a working party to draft the agenda and declaration of the 1997 UNESCO world conference on Adult Education, he took part as a discussant and participant in various UNESCO reviews and workshops. He was invited to speak at innumerable conferences, and universities; he was asked to assess research proposals for research councils as far flung as Hong Kong and Australia, and for the European Commission. He was asked to chair the Editorial Board of Comparative Education: and although probably never strictly a 'comparativist', he was well-qualified to do so. A member of the board since 1991, his interests in international lifelong education were long-standing; his international networks and reputation were excellent; he had been honorary president of the British Association for International and Comparative Education in 1999-2000. He is also excellent at peace-making and encouraging small groups of people to get along.

And of course the books continued. Finalising the five volumes of Adult and Continuing Education: Major Themes in Education was no mean task. Peter had recently updated Twentieth Century Thinkers, addressing - with partial success - the absence of women as authors or subjects in the original edition (Jarvis, 2001d). He now worked on new editions of several other authored and edited works (Jarvis, Holford, and Griffin (2003), Jarvis and Stannett (2003), Jarvis (2004)). There were also two new collections exploring different aspects of learning: Human Learning: An Holistic Approach (Jarvis \& Parker, 2005) and International Perspectives on Experiential Learning (Jarvis, West, \& Mijoc, 2006). These must have contributed to Peter's imagining what may prove his most substantial single contribution: the trilogy Lifelong Learning and the Learning Society. Although he 'had a little health scare' (Jarvis, 2006, p. xii) when he started on the first volume - Peter is given to understatement on his health - the three volumes of this work (Jarvis (2006) (2007) (2008)) 
appeared in rapid succession. Most of the articles in this volume refer to them, but it is worth drawing attention to certain features. They represent a return to the central themes of Peter's work: learning as a social phenomenon. Everyone, he argued, 'is a human existent born into human society and through individual learning the human essence emerges and develops, and ... for as long as we live and stay engaged in society that learning continues' (Jarvis, 2006, p. 199). But if the first volume (Towards a Comprehensive Theory of Human Learning) develops the arguments on learning processes which he first elaborated twenty years earlier (Jarvis, 1987a), the second and third connect these to more contemporary and political issues. In Globalisation, Lifelong Learning and the Learning Society (Jarvis, 2007) we are thrown up against the major challenges of our times: 'the emergence of lifelong learning and the learning society is but a short one in the history of the world - probably less than half a century', but over this time 'the ecology has been put at risk like never before, [and] humanity is divided between those who have and those who have not ... We do need lifelong learning that asks questions about the future of humanity and the future of the planet and these should be seen as [as] important as employability and more important than corporate profit' (Jarvis, 2007, p. 202).

In the third volume of the trilogy, Democracy, Lifelong Learning and the Learning Society: Active citizenship in a late modern age (Jarvis, 2008), Peter is at his most political - though he has never been as overtly 'political' as many in adult education. But we are left in no doubt as to where he stands: we should aim for 'a totally different form of learning society', one that

starts with the learning community - the community learning to live together. The emphasis really should be on learning - we need to learn to live together and this must be our primary aim if humankind is to survive. ... [Although] the small community is a totally different social form to the larger society, ... we need to capture something of the ethos of community in all aspects of social governance. (Jarvis, 2008, p. 214).

While Peter's commitment to democracy and participation have long been central features of his understanding of learning, this line of thinking was clearly influenced by his involvement in a major European Commission project on lifelong learning, governance and active citizenship in the early 2000s. ${ }^{19}$

If we are to create active citizens we need a learning people whose learning is also practical: a people prepared to seek to understand the complexities of contemporary society and give time and effort to be involved in helping solve the problems: we need people who understand the risks of today's society. In this sense, we need an open democratic society in which the people regard it as their responsibility to learn and to play their role, so that we can all respond to the needs of everyone in social living. (Jarvis, 2008)

For many people, the publication of such a trilogy at the end of a long and distinguished career would have been sufficient. Not for Peter. The following year saw the publication of what may turns out to be the most developed statement of his views on learning: Learning to be a Person in Society (Jarvis, 2009a), along with The Routledge International Handbook of Lifelong Learning (Jarvis, 2009b) and a jointly-edited book on Universities, Ethics and Professions (Barnett, Strain, \& Jarvis, 2009). Then on to the fourth edition of Theory and Practice (Jarvis, 2010), and another major Routledge International Handbook, this time on Learning (Jarvis \& Watts, 2012). Whilst there have been no 
books since, he has written some very thoughtful and reflective papers (e.g. Jarvis (2013), (2014)), co-edited a special issue of Comparative Education (Han \& Jarvis, 2013), and contributed conceptually to another major compilation, The Palgrave International Handbook of Adult and Lifelong Education and Learning (Milana, Webb, Holford, Waller, \& Jarvis, 2017).

Throughout this time, of course, Peter continued to co-edit the International Journal of Lifelong Education. (He has once or twice described it as 'the best thing I've done' - which, considering everything else, is praise indeed.) Honours are not, of course, always achievements, but with Peter neither have been in short supply. In 2010 he was made Emeritus Professor at Surrey. We have seen that he received the AAACE's Houle Award for Literature in Adult Education in 1988; it came a second time in 2008 (this time for Globalisation, Lifelong Learning and the Learning Society). Honorary doctorates have come from several universities: Helsinki, City (London), Nottingham, Pécs (Hungary), Piteşti (Romania), and he has honorary fellowships, professorships and medals not only from many more universities, but from adult education associations and institutions. He was for many years an Adjunct Professor in Adult Education at the University of Georgia. He was inducted into the International Adult and Continuing Education Hall of Fame in 1997; ${ }^{20}$ he is an Academician of the British Academy of Social Sciences. As long ago as 1997, on the basis of his published work, he was awarded a higher doctorate (D.Litt.) by the University of Surrey - the first D.Litt. Surrey awarded.

\section{Articles and Authors}

This double special issue comprises fifteen articles. They are grouped into four parts, broadly reflecting areas of Peter's scholarly interest and intervention. However, Peter's wide reading and interests, and his capacity to see links between diverse areas of scholarship, mean the boundaries between these parts are inevitably fuzzy.

Part I, Understanding Learning, begins with Martin Dyke's 'Paradoxes of a Long Life Learning: an Exploration of Peter Jarvis's Contribution to Experiential Learning Theory'. Martin, once Peter's doctoral student and now at the University of Southampton, explores how Peter's modelling of the learning process emerged from his understanding of experiential learning, and how it has developed; he also shows interesting parallels with Margaret Archer's work. Knud Illeris, of Aarhus University, who contributes the second paper, is of course a most distinguished scholar: it is testament to Peter's standing that Knud has chosen to contribute what he thinks will ('probably') be the last of his nearly 500 academic articles to this collection. 'Peter Jarvis and the understanding of adult learning' compares Peter's theorisation of learning with Knud's own and with Etienne Wenger's: they are, he believes, complementary. Patti Gouthro, of Mount St Vincent University, Canada, who contributes the third paper, is a not only a leading scholar but formerly one of Peter's co-editors on this journal. 'The promise of lifelong learning' explores Peter's work on wisdom and the meaning and purpose of lifelong learning: drawing on her own research on fiction writers, she shows how his work can illuminate biographical- and life-history-based research. Finally, the distinguished Australian philosopher of adult education, Richard Bagnall, of the University of Queensland, develops 'A critique of Peter Jarvis's conceptualisation of the lifelong learner in the contemporary cultural context'. Richard is not convinced that Peter's theorisation covers all forms of 
learning, but finds its 'strongly existentialist and humanistic view of the learner ... stimulating and appealing'.

In Part II, Learning and the Meaning of Life, three papers move from the theorisation of learning as such to its relation with broader issues of human community, co-existence and belief. This part begins with a paper jointly authored by two American adult educators who have worked with Peter and his writings. In '(Critical) learning in/through everyday life in a global consumer culture', Robin Redmon Wright of Penn State University and Jenny Sandlin of Arizona State University look at three areas of Peter's work which have influenced them: learning from everyday life and in social context; incidental and tacit learning in globalised consumer societies; and adult learning, citizenship, and activism. His work, they suggest, provides a basis for new avenues of exploration, drawing on a posthumanist, radical view of adult learning and identity development. Peter's Methodist calling has been a continuous thread, perhaps understated in his work until more recently. In 'Learning is an ontological process: Jarvis and theories of Christian Religious Education in dialogue', Alison Le Cornu of Queen's Theological Foundation, Birmingham - also one of Peter's former doctoral students raises questions about experiential learning, the nature of the whole person, and the relationship between learning and teaching in human becoming. Finally in this part, in 'Opening spaces of conversation: citizen education for newcomers as a democratic practice', Danny Wildemeersch of the Catholic University, Leuven - a leading theorist and practitioner of adult education ('social pedagogy') - moves our attention to one of the pressing problems of our time. Starting from Peter's position that the only 'universally valid' value in educational practice is 'caring for the Other', he explores what a 'non-instrumentalising' citizenship education might comprise.

Part III consists of three articles addressing aspects of Adult Education, Citizenship and Democracy. The first explores some of the roots of the forms of adult education Peter has espoused. 'Resisting the enormous condescension of posterity: Richard Henry Tawney, Raymond Williams and the long struggle for a democratic education', by Linden West of Christ Church University, argues cultivating $1 /$ thou experience across difference was central to early- and mid-twentieth century British workers' education - traditions important to the ethos of adult education during Peter's first decade at Surrey. Moosung Lee, from the University of Canberra, next turns to the rather different topic of how 'self-help' books depict adult learners. 'Decoding the neoliberal subjectivity in self-helping adult learners', he finds them expected to show rational and responsible self-management, excessive selfpositivity, voluntary self-exploitation and loosely connected selves with no solidarity. Finally, John Field of Stirling University and Michael Schemmann of the University of Cologne bring together a number of topics which have interested Peter - globalisation, active citizenship and sociological theory - in a paper entitled 'International organisations and the construction of the learning active citizen: An analysis of adult learning policy documents from a Durkheimian perspective'.

Part IV, entitled Global and Local, tries to capture a little of the range of Peter's scholarship and engagement. Its four articles begin with 'Wide horizons and blurred boundaries: comparative perspectives on adult and lifelong learning' by Lore Arthur of the Open University and Michael Crossley of Bristol University. Peter taught Lore on the Surrey M.Sc., and later supervised her Ph.D.; Michael was for many years a colleague of Peter's on the Comparative Education editorial board. They show how Peter's global framing of lifelong learning had an impact on both adult and comparative education as fields of inquiry. Julia Preece - once Peter's colleague at Surrey, but now 
at the University of Kwazulu-Natal - devotes the second paper to 'Globalisation in Africa: reflecting on Peter Jarvis's superstructure and substructure model'. Using a postcolonial lens, she develops a critique of how learning opportunities in African situations are facilitated and manipulated through the globalisation process. In the third article, another doyen of adult education - Roger Boshier of the University of British Columbia - addresses how 'Chinese students speak about their favourite teachers and university reform'. Like Peter, Roger's engagement with Chinese higher education goes back to the 1980s: his research suggests Chinese students' preoccupations reflect 'humanist and radical humanist paradigms' rather than officially-approved 'functionalist notions of globalization'.

In an alternative organisation, the final article in Part IV might well have been the first in the entire collection. Alan Tuckett may now be with the University of Wolverhampton, but like Peter he has devoted his career to adult education, above all as Director of the National Institute of Adult Continuing Education for 23 years. We can see his study of 'The rise and fall of life-wide learning for adults in England' as setting out the local - in the sense of national - policy context within which Peter led his professional life. But it is much more than this: it is a powerful, polemical, yet deeply informed critique of the now-dominant of a 'utilitarian' approach to adult learning; it is an account of how it became dominant; and it demonstrates how important the 'life-wide' adult education Peter has long advocated must remain in any learning society.

\section{Conclusion}

'No prophet is accepted in his own country.' (Luke, 4:24)

Peter's friends and admirers have occasionally mused that his contribution has been recognised more abroad than in his home country. Perhaps it is his own fault: though a great networker and traveller, he has not been an accomplished schemer. In any case, he has preferred community service to climbing the greasy pole. ${ }^{21} \mathrm{His}$ character, and his calling, are well-captured in the quotation from Chaucer with which this paper began: gladly has he learned, and gladly taught. For Peter, the two are inseparable. And in teaching, as in thinking and writing about education, his leitmotif has been care. Yet it is right to point out - as Peter often does point out - that if he is recognised abroad, this is very much because he finds home so caring. Maureen and he have been married since 1962. Peter's appetite for hard work - from well before the crack of dawn - is legendary, but Maureen made it possible. Their children, Frazer and Kierra, must also have contributed. All are acknowledged, time and again, in his books - but as Peter wrote in one of his more recent prefaces 'one person above all' - Maureen - 'has supported and encouraged me, has always been there when I needed her' (Jarvis, 2007, p. xii).

Peter began his working life as a Methodist minister. While this has not been his (paid) vocation since the 1960s, a theological lens has always been part of his intellectual - and one suspects his emotional - armoury. That he has been a driven and ambitious scholar none will doubt, but there has always been more to him than ambition. The ambition has been to a purpose; and his purpose has been much more than personal advancement. It has been, in a very humane way, the encouragement of learning directed to the growth of human community. In this respect, it seems apposite to end with a quotation from the founder of Methodism, John Wesley. Early Methodists 
were, of course, often outsiders - shunned by the majority, and in particular by other Christians. People would represent them 'sometimes as madmen and fools, sometimes as wicked men, fellows not fit to live upon the earth'. To use a phrase of Peter's, they were 'the Other'. But Wesley's advice to them was clear:

Condemn no man for not thinking as you think: Let every one enjoy the full and free liberty of thinking for himself: Let every man use his own judgment, since every man must give an account of himself to God. Abhor every approach, in any kind or degree, to the spirit of persecution. If you cannot reason or persuade a man into the truth, never attempt to force him into it. (Wesley, 1745)

It is an approach to which, knowingly or unconsciously, Peter has adhered. 


\section{References}

Barnett, R., Strain, J., \& Jarvis, P. (Eds.). (2009). Universities, Ethics and Professions: Debate and Scrutiny. Abingdon: Routledge.

Brookfield, S. (Ed.). (1987). Learning Democracy: Eduard Lindeman on Adult Education and Social Change. Beckenham: Croom Helm.

Brownhill, R. J. (1983). Education and the Nature of Knowledge. London: Croom Helm.

Brownhill, R. J., \& Smart, P. (1988). Political Education. Beckenham: Croom Helm.

Chadwick, A. F. (1980). The role of the museum and art gallery in community education. Nottingham: Department of Adult Education, University of Nottingham for the National Institute of Adult Education.

Chaucer, G. (1977). The Canterbury Tales. Translated into modern English by Nevill Coghill. Harmondsworth: Penguin.

Collins, M. (1991). Adult Education as Vocation: A Critical Role for the Adult Educator. London: Routledge.

Courtney, S. (1991). Why Adults Learn: Toward a Theory of Participation in Adult Education. London: Routledge.

Department for Education and Employment. (1998). The Learning Age: A Renaissance for a New Britain. London.

Douglas, R. (1991). Surrey: the Rise of a Modern University. Guildford: Surrey University Press.

Elton, L., \& Manwaring, G. (1979). Towards a staff development programme in South East Asia. Overseas Universities, 26, 20-24

Elton, L., Oliver, E., \& Wray, M. (1986). Academic staff training at a distance: a case study. Programmed Learning and Educational Technology, 23(1), 29-40

Gelpi, E. (1985). Lifelong Education and International Relations. Beckenham: Croom Helm.

Griffin, C. (1982). Curriculum Analysis of Adult and Lifelong Education. International Journal of Lifelong Education, 1(2), 109-121. doi: 10.1080/0260137820010203

Griffin, C. (1983a). Curriculum Theory in Adult and Lifelong Education. Beckenham: Croom Helm.

Griffin, C. (1983b). Social Control, Social Policy and Adult Education. International Journal of Lifelong Education, 2(3), 217-244. doi: 10.1080/0260137830020302

Griffin, C. (1987). Adult Education: As Social Policy. Beckenham: Croom Helm.

Han, S., \& Jarvis, P. (Eds.). (2013). Dialogue of the East and the West: Searching for New Perspectives. (Special Issue of Comparative Education) (Vol. 49). Abingdon: Taylor \& Francis.

Hargreaves, P., \& Jarvis, P. (1998). The Human Resource Development Handbook. London: Kogan Page.

Haycocks, N. (1978). The Training of Adult Education and Part-time Further Education Teachers. London: Advisory Committee of the Supply and Training of Teachers.

Heron, J. (1971). Experience and Method: An Inquiry into the Concept of Experiential Research. Guildford: Human Potential Research Project, Department of Educational Studies, University of Surrey.

Heron, J. (2012). My Early Engagement with Humanistic Psychology. Self \& Society, 40(1), 48-55

Holford, J., Jarvis, P., \& Griffin, C. (Eds.). (1998). International Perspectives on Lifelong Learning. . London: Kogan Page.

Holford, J., \& van der Veen, R. (2006). Lifelong Learning, Governance and Active Citizenship in Europe: ETGACE Project Final Report. Luxembourg: Office for Official Publications of the European Communities.

Holford, J., \& Welikala, T. (2013). 'Renaissance' without enlightenment: New Labour's 'Learning Age' 1997-2010. In E. Saar, O. B. Ure \& J. Holford (Eds.), Lifelong learning in Europe: national patterns and challenges (pp. 140-164). Cheltenham: Edward Elgar 
Illeris, K. (2007). How We Learn: Learning and non-learning in school and beyond. Abingdon: Routledge.

Illeris, K. (Ed.). (2009). Contemporary Learning Theories: Learning theorists ... in their own words. Abingdon: Routledge.

Jarvis, P. (1972). Religious socialization in the junior school : an enquiry among class teachers.

(M.Soc.Sc. dissertation), University of Birmingham.

Jarvis, P. (1977). A Profession in Process: the relationship between occupational ideology, occupational position and the role strain, satisfaction and commitment of Protestant and Reformed ministers of religion. (PhD thesis), Aston University.

Jarvis, P. (1983a). Adult and Continuing Education: Theory and Practice. Beckenham: Croom Helm.

Jarvis, P. (1983b). Adult Education and the Elderly. Adult Education, 55(4), 343-350

Jarvis, P. (1983c). Professional Education. Beckenham: Croom Helm.

Jarvis, P. (1984). Andragogy - a Sign of the Times. Studies in the Education of Adults 16(1), 32-38. doi: 10.1080/02660830.1984.11730438

Jarvis, P. (1985). The Sociology of Adult and Continuing Education. Beckenham: Cfoom Helm.

Jarvis, P. (1987a). Adult Learning in the Social Context. Beckenham: Croom Helm.

Jarvis, P. (1990). An International Dictionary of Adult and Continuing Education. London: Routledge.

Jarvis, P. (1992). Paradoxes of Learning: On becoming an individual in society. San Francisco, CA: Jossey-Bass.

Jarvis, P. (1993). Adult Education and the State: Towards a politics of adult education. London: Routledge.

Jarvis, P. (1995). Adult and Continuing Education: Theory and Practice (2nd ed.). London: Routledge. Jarvis, P. (1997). Ethics and Education for Adults in a Late Modern Society. Leicester: NIACE.

Jarvis, P. (1998). The Practitioner Researcher: Developing Theory from Practice San Francisco: JosseyBass.

Jarvis, P. (2001a). Learning in Later Life: An Introduction for Educators and Carers. London: Kogan Page.

Jarvis, P. (2001b). Universities and Corporate Universities: The Higher Learning Industry in Global Society. London: Kogan Page.

Jarvis, P. (2004). Adult Education and Lifelong Learning: Theory and Practice (3rd ed.). London: Routledge.

Jarvis, P. (2006). Towards a Comprehensive Theory of Human Learning. Abingdon: Routledge.

Jarvis, P. (2007). Globalisation, Lifelong Learning and the Learning Society: Sociological Perspectives. Abingdon: Routledge.

Jarvis, P. (2008). Democracy, Lifelong Learning and the Learning Society: Active citizenship in a late modern age. Abingdon: Routledge.

Jarvis, P. (2009a). Learning to be a Person in Society. Abingdon: Routledge.

Jarvis, P. (2010). Adult Education and Lifelong Learning: Theory and Practice (4th ed.). Abingdon: Routledge.

Jarvis, P. (2013). Learning to be a Person - East and West. Comparative Education, 49(1), 4-15. doi: 10.1080/03050068.2012.740216

Jarvis, P. (2014). From adult education to lifelong learning and beyond. Comparative Education, 50(1), 45-57

Jarvis, P. (Ed.). (1987b). Twentieth Century Thinkers in Adult Education. Beckenham: Croom Helm.

Jarvis, P. (Ed.). (1988). Britain: Policy and Practice in Continuing Education (Vol. 40). San Francisco: Jossey-Bass.

Jarvis, P. (Ed.). (2001c). The Age of Learning: Education and the knowledge society. London: Kogan Page.

Jarvis, P. (Ed.). (2001d). Twentieth Century Thinkers in Adult and Continuing Education (2nd ed.). London: Kogan Page. 
Jarvis, P. (Ed.). (2002). The Theory and Practice of Teaching. London: Kogan Page.

Jarvis, P. (Ed.). (2009b). The Routledge International Handbook of Lifelong Learning. Abingdon: Routledge.

Jarvis, P., \& Chadwick, A. F. (Eds.). (1991). Training Adult Educators in Western Europe: Routledge in association with the European Bureau of Adult Education.

Jarvis, P., \& Gibson, S. (1981). An investigation into the validity of specifying 5'O' levels in the General Certificate of Education as an entry requirement for the education and training of district nurses. Journal of Advanced Nursing, 6, 471-482. doi: 10.1111/j.13652648.1981.tb03251.x

Jarvis, P., \& Gibson, S. (1985). The Teacher Practioner in Nursing, Midwifery and Health Visiting. Beckenham: Croom Helm.

Jarvis, P., \& Gibson, S. (1997). The Teacher Practitioner and Mentor in Nursing, Midwifery, Health Visiting and the Social Service (2nd ed.). Cheltenham: Stanley Thornes

Jarvis, P., \& Griffin, C. (Eds.). (2003a). Adult and Continuing Education: Major Themes in Education (Vol. I: Liberal Adult Education (Part 1)). London: Routledge.

Jarvis, P., \& Griffin, C. (Eds.). (2003b). Adult and Continuing Education: Major Themes in Education (Vol. II: Liberal Adult Education (Part 2)). London: Routledge.

Jarvis, P., \& Griffin, C. (Eds.). (2003c). Adult and Continuing Education: Major Themes in Education (Vol. IV: Teaching, Learning and Research). London: Routledge.

Jarvis, P., \& Griffin, C. (Eds.). (2003d). Adult and Continuing Education: Major Themes in Education (Vol. III: Vocational Education). London: Routledge.

Jarvis, P., \& Griffin, C. (Eds.). (2003e). Adult and Continuing Education: Major Themes in Education (Vol. V: Adult Education - Viewed from the Disciplines). London: Routledge.

Jarvis, P., Griffin, C., Holford, J., Merricks, L., \& Tosey, P. (1998). Why lifelong learning is not a policy. The Times Higher Education Supplement

Jarvis, P., Holford, J., \& Griffin, C. (1998). The theory and practice of learning. London: Kogan Page. Jarvis, P., Holford, J., \& Griffin, C. (2003). The theory and practice of learning (2nd ed.). London: Kogan Page.

Jarvis, P., Holford, J., Griffin, C., \& Dubelaar, J. (1997). Towards the Learning City: An Evaluation of the Corporation of London's Adult Education Voucher Schemes. London: Corporation of London Education Department.

Jarvis, P., Rabušicová, M., \& Nehyba, J. (2015). Adult Learning as a Lifelong Concern: Interview with Peter Jarvis Studia paedagogica, 20(4), 109-122. doi: 10.5817/SP2015-4-7

Jarvis, P., \& Stannett, A. (Eds.). (2003). Perspectives on Adult Education and Training in Europe (2nd ed.). Leicester: NIACE.

Jarvis, P., \& Walters, N. (Eds.). (1993). Adult Education and Theological Interpretations. Malabar, FL: Krieger Publishing Company.

Jarvis, P., \& Watts, M. (Eds.). (2012). The Routledge International Handbook of Learning. Abingdon: Routledge.

Jarvis, P., \& Wilson, A. L. (1999). International Dictionary of Adult and Continuing Education (2nd ed.). London: Kogan Page.

Jensen, G., Liveright, A. A., \& Hellenbeck, W. (Eds.). (1964). Adult Education: Outlines of an Emerging Field of University Study. Washington, DC: American Association for Adult and Continuing Education.

MacDougall, P. (1981). The Chatham Dockyard Story. Rochester: Rochester Press.

Marsick, V. (Ed.). (1987). Learning in the Workplace. Beckenham: Croom Helm.

Milana, M., Webb, S., Holford, J., Waller, R., \& Jarvis, P. (Eds.). (2017). The Palgrave International Handbook of Adult and Lifelong Education and Learning Basingstoke: Palgrave Macmillan. 
National Advisory Group for Continuing Education and Lifelong Learning. (1997). Learning for the Twenty-First Century: First Report of the National Advisory Group for Continuing Education and Lifelong Learning: NAGCELL.

Olssen, M. (1999). Michel Foucault: Materialism and Education Westport, CT: Bergin \& Garvey.

Peters, J. M., \& Jarvis, P. (Eds.). (1991). Adult Education: Evolution and Achievements in a Developing Field of Study. San Francisco: Jossey-Bass.

Pope, M. L., \& Denicolo, P. (2000). Transformative Education: Personal Construct Approaches to Practice and Research. London: Whurr.

Pope, M. L., \& Keen, T. R. (1981). Personal Construct Psychology and Education. London: Academic Press.

Usher, R., \& Edwards, R. (1994). Postmodernism and Education. London: Routledge.

Watkins, K. E., \& Marsick, V. J. (1990). Informal and Incidental Learning in the Workplace. London: Routledge.

Wesley, J. (1745). Advice to a People Called Methodist (10 October). Retrieved from http://www.umcmission.org/Find-Resources/John-Wesley-Sermons/The-Wesleys-and-TheirTimes/Advice-to-a-People-Called-Methodist

Whitty, G., \& Young, M. (Eds.). (1976). Explorations in the Politics of School Knowledge. Driffield: Nafferton Books.

Young, M. (Ed.). (1971). Knowledge and Control: New Directions for the Sociology of Education. London: Collier-Macmillan.

Young, M., \& Whitty, G. (Eds.). (1977). Society, State and Schooling: Readings on the Possibilities for Radical Education. Lewes: Falmer Press.

\footnotetext{
${ }^{1}$ The quotation is from The Prologue to the Canterbury Tales, lines. This passage has been rendered into modern English by Nevil Coghill as 'A tone of moral virtue filled his speech, and gladly would he learn, and gladly teach' (Chaucer, 1977, p. 10).

${ }^{2}$ George Orwell tried his hand at hop-picking - 'in the category of things that are great fun when they are over', he wrote (Blair, 1931).

${ }^{3}$ Peter's M.Soc.Sc. dissertation (Jarvis, 1972) can be consulted in the University of Birmingham Library; an electronic copy of his Ph.D. thesis (Jarvis, 1977) can be downloaded from either Aston University Library or the British Library.
}

${ }^{4}$ Surrey had been 'promoted' from the status of College of Advanced Technology to become a University only in 1966, though its origins go back to Battersea Polytechnic, founded in 1891 (Douglas, 1991). The Department of Adult Education had recently taken over university extra-mural provision (under the 'Responsible Body' arrangements) in the county of Surrey along with some outer London boroughs, from the University of London.

\footnotetext{
${ }^{5}$ They included the polymathic Lewis Elton, founder of the Society for Research into Higher Education originally a physicist but by the 1980s perhaps the leading figure in the development of teaching methodologies for higher education; John Heron, an innovator in participatory research and co-operative inquiry (though their times at Surrey overlapped only briefly, Heron's approach took root in the Department's Human Potential Research Group) (Heron, 1971, 2012); the personal construct psychologist Maureen Pope (later joined by Pam Denicolo) (Pope \& Denicolo, 2000; Pope \& Keen, 1981); the learned and intellectually generous historian of liberal adult education Alan Chadwick (Chadwick, 1980); and two philosophers who turned their attention to adult education Pat Smart and Bob Brownhill (Brownhill, 1983; Brownhill \& Smart, 1988).
} 
${ }^{6}$ In this Peter was able to build on work done by Lewis Elton (Elton \& Manwaring, 1979; Elton, Oliver, \& Wray, 1986), whose distance learning Diploma in the Practice of Higher Education had found students all over the world; Peter's modules extended this into other areas of post-compulsory education.

${ }^{7}$ Not merely in the English-speaking world: it was translated into languages as diverse as Chinese, Estonian, Greek and Hungarian.

${ }^{8}$ It was, however, reprinted and translated into Spanish, and reprinted in part for an Open University course.

${ }^{9}$ From its inception, Peter was joint editor of the International Journal of Lifelong Education with J.E. (Teddy) Thomas of the University of Nottingham; however, in a speech at a dinner to mark the journal's $25^{\text {th }}$ anniversary, Teddy had no qualms about describing Peter as the 'driving force'.

${ }^{10}$ After Croom Helm was taken over by Routledge in 1988, the two series were renamed International Perspectives on Adult and Continuing Education and The Routledge Series on the Theory and Practice of Adult Education in North America.

${ }^{11}$ This is awarded for 'a book published in English in the previous year that reflects universal concerns of adult educators'. They must be 'outstanding literature in adult education ... relevant to adult educators in more than one country, exemplify high standards of scholarship ... [and] contribute significantly to the advancement of adult education as a unified field of study and practice' (http://www.aaace.org/?page=CyrilOHoule; accessed 9 February 2017).

12 Connecticut, Cornell, Georgia, Maryland, Missouri, Northern Illinois, Tennessee, and Teachers College, Columbia, among others.

${ }^{13}$ Paul Tosey (a successor to John Heron in the Human Potential Research Group), the social historian Linda Merricks, Julia Preece (later to move to chairs in Adult Education at Glasgow and several African universities), Bob Brownhill, and occasionally others.

${ }^{14}$ In fact, Peter's curriculum vitae includes few funded research projects. While this may have delayed his promotion at Surrey, it is hard to believe it limited his contribution to human knowledge and understanding.

${ }^{15}$ This project began in 1996; Peter, Colin and I worked on it for three years, but around 1999 administrative responsibilities at Surrey forced me to drop out.

${ }^{16}$ See esp. Griffin (1999a) and Griffin (1999b), which both developed from papers Colin read to the group in 1997 and 1998.

${ }^{17}$ I recall in particular one occasion, when Peter, Colin and I were working on The Theory and Practice of Learning. The afternoon before we were all three to meet to discuss our chapter drafts, Colin and I met by chance in the Department's post-room. Sheepishly, we admitted to one another that neither of us had made any progress. 'But,' said Colin, 'I've got some some good news: Peter hasn't started his either!' By the time all three of us met the following day, we discovered that overnight Peter had not only started but completed his draft chapter: and it was good.

${ }^{18}$ The new department was initially named 'Political, International and Policy Studies'; this was later simplified. From time to time it has been branded a School.

19 'Education and Training for Governance and Active Citizenship in Europe' (ETGACE). This was funded by the European Commission under its $5^{\text {th }}$ Framework research programme. Participating researchers incuded Danny 
Wildemeersch, Ruud van der Veen, Vida Morhorčič Špolar, Kari Nurmi, and John Holford. See Holford and van der Veen (2006).

${ }^{20}$ http://www.halloffame.outreach.ou.edu (accessed 10 February 2017).

${ }^{21}$ On moving to Thatcham, he founded a branch of the U3A: he received a Gold Civic Award from Thatcham Town Council in 2010 in recognition of this, and in 2015, he was awarded a certificate as 'Member No. 1' for his 'service in founding and establishing the Thatcham U3A'. 